\title{
Analisis Video Share to Video Like Ratio Tiktok Pada Top 5 Brand Handphone Terlaris Di Dunia
}

\author{
Satria Wangsa \\ STIMIK STIKOM Indonesia \\ Wangsa.toeban@gmail.com
}

\begin{abstract}
ABSTRAK
Tiktok merupakan aplikasi video kreasi yang dilengkapi music dan font. Tiktok dipakai untuk membagikan video kreatif mulai dari bernyanyi, tarian, make up, memasak, dan lainnya. Pengguna tiktok di Indonesia menurut jumlah unduhan baik di google play dan app store berada di kisaran 300 juta pengguna yang menjadikan indonsia salah satu pengguna aplikasi tiktok terbesar di dunia.Tiktok sebagai platform media social juga di gunakan sebagai social media marketing, ini merupakan kesempatan brand untuk mengenal produk ke masyarakt lebih luas. Adapun 5 perusahaan yang menawarkan brand handphone antara lain : Samsung, Huawei, oppo, xiaomi, apple. Tujuan penelitian tersebut untuk menghitung kredibilitas dari peforma setiap akun perusahaan di tiktok. Metode yang digunakan untuk penelitian ini yaitu metode eksploratif kuantitatif. Hasil dari penelitian ini menunjukan bahwa handphone terlaris di dunia adalah apple mendapatkan peringkat pertama dan memiliki kredibilitas performa akun yang baik.
\end{abstract}

Keyword : Credibility Account TikTok; Social Media Marketing ; Social Media TikTok ; Video Share to Video Like ratio; Hanphone terlaris di dunia.

\begin{abstract}
ABSTRAK
Tiktok is a creative video application that is equipped with music and fonts. Tiktok is used to share creative videos ranging from singing, dancing, makeup, cooking, and more. Tiktok users in Indonesia according to the number of downloads both on google play and the app store are in the range of 300 million users, which makes Indonesia one of the largest users of the tiktok application in the world. Tiktok as a social media platform is also used as social media marketing, this is a brand opportunity to get to know the product to the wider community. The 5 companies that offer mobile phone brands include: Samsung, Huawei, oppo, xiaomi, apple. The purpose of this study is to calculate the credibility of the performance of each company account on tiktok. The method used for this research is quantitative exploratory method. The results of this study indicate that the best-selling mobile phone in the world.
\end{abstract}

Keyword: TikTok Account Credibility; Social Media Marketing ; Social Media TikTok ; Video Share to Video Like ratio; Best selling cell phone in the world. 


\section{PENDAHULUAN}

Indonesia saat ini berdasarkan studi Poling Indonesia dan berkerja sama assosiasi penyelenggaraan jasa internet di Indonesia (APJII) menyatakan bahawa pengguna internet di Indonesia berjumlah 171,17 juta jiwa bila di persentasikan dalam persentase pengguna internet di Indonesia berjumlah sekitar 64\%.Angka tersebut sangat besar tentunya membuat masyarakat Indonesia mengalami perubahan budaya ataupun promosi dalam bermedia social pada saat ini. Aplikasi tiktok di tahun 2020 berkembang pesat dan menjadi budaya baru di Indonesia. Meskipun aplikasi tersebut sudah ada sejak tahun 2018 namun belakangan ini aplikasi tersebut banyak digandrungi oleh masyarakat berbagai usia. Pada awal munculnya aplikasi tersebut sempat diblokir oleh Kementerian Komunikasi dan Informatika dengan alasan aplikasi tersebut memberikan dampak negatif untuk anak - anak. Setelah 2 tahun berlangsung aplikasi tik tok menjadi trend dan budaya baru buat masyarakat Indonesia (Dewa and Safitri 2021).

Tiktok menunjukan performa tingkat keterlibatan (engagement rate) yang lebih tinggi dibandingkan social media berbasis video lainnya seperti Instagram dan YouTube. Studi yang dilakukan Geyser, menunjukan performa dari micro-influenccer TikTok memiliki tingkat keterlibatan (engagement rate) sebesar 17,96\%, Instagram 1,63\% dan YouTube 0,37\% yang digambarkan melalui grafik berikut ini besar untuk meningkatkan kesadaran merek suatu produk di pasaran yang ditunjukan dari hasil analisis korelasi bivariat yang moderat. Besarnya jumlah pengguna tiktok di indoneisa memberikan peluang kepada brand unutk mempromosikan produknya melalui media social. Adapun beberapa perusahaan top dalam memeperkenalkan produk melalui media sosisal contohnya seperti 5 band handphone terlaris di dunia diantaranya Samsung, Oppo, Xiaomi ,Huawai ,Appel.

Penelitian ini menggunakan metode eksploratif kuantitatif, dan akan menghitung menggunakan rasio-rasio yang ada pada TikTok. Pada penelitian (Permana and Meinarni 2021) menjelaskan bahwa terdapat 17 rasio yang ada pada sosial media TikTok dan relevan digunakan sebagai media ukur kredibilitas akun yang ada. Penelitian ini hanya berfokus untuk menghitung kredibilitas

Video Likes to Video Share Ratio pada Top 5 Vendor Smartphone di Indonesia. Adapun 5 brand handphone terlaris di dunia , diantaranya yaitu : Oppo, Samsung, Xiomi, Huawai, Appel. Tujuan dari penelitian ini adalah mengetahui kredibilitas performa dari akun TikTok 5 Brand Handphone Terlaris Di Dunia menggunakan Video Likes to Video Share Ratio.

\section{TINJAUAN PUSTAKA}

Indonesia saat ini berdasarkan studi Poling Indonesia dan berkerja sama assosiasi penyelenggaraan jasa internet di Indonesia (APJII) menyatakan bahawa pengguna interternet di Indonesia berjumlah 171,17 juta jiwa bila di persentasikan dalam persentase pengguna internet di Indonesia berjumlah sekitar 64\%.Angka tersebut sangat besar tentunya membuat masyarakat Indonesia mengalami perubahan budaya ataupun promosi dalam bermedia social pada saat ini. Aplikasi tiktok di tahun 2020 berkembang pesat dan menjadi budaya baru di Indonesia. 
Aplikasi Tik Tok atau yang lebih dikenal dengan Douyin, secara harfiah berasal dari Cina, dan diluncurkan pada bulan September 2016 oleh Zhang Yiming. Aplikasi Tik Tok adalah platform video pendek yang dibuat dengan durasi 15 detik yang berbasis sosial dan didukung musik. Aplikasi Tik Tok digunakan untuk merekam, mengedit dan mengunggah ke beberapa media sosial sehingga dapat dilihat oleh teman-teman baik sesama pengguna aplikasi Tik Tok maupun yang bukan pengguna aplikasi Tik Tok, yang membedakannya dengan media sosial lain adalah aplikasi Tik Tok memiliki berbagai macam fitur yang bisa dinikmati penggunannya seperti adanya fitur spesial effects yang terdiri dari effects shaking dan shivering yang berfungsi untuk menciptakan sebuah video yang menarik, selain itu dilengkapi dengan fitur music backround dari berbagai artis terkenal dari berbagai penjuru dunia, dan fitur wajah yang penggunanya dapat membuat video dengan berbagai rupa tampilan wajah unik mulai dari wajah lucu, seram, sedih, marah dan lainlain (Fauziah 2019).

Aplikasi ini banyak digemari oleh para remaja, anak kecil, bahkan sampai pada orang dewasa yang merasa mmbutuhkan hiburan. Konon aplikasi ini memiliki nama lain aplikasi "goblok". Banyaknya anak muda maupun dewasa yang membuat dan memposting video diberbagai platform media sosialnya membuat tidak hanya aplikasi ini semakin popular namun orang yang menggunakan aplikasi "goblok" ini ikut popula. Sebagai salah satu media sosial tik tok memberikan sarana berbagi konten yang sangat bervariasi dari segi kreativitas, video challenge, lipsync, lagu, menari, bernyanyi dan lain lain. Karena banyaknya yang menggunakan maka Tik Tok memberikan peluang sebagai sarana promosi (Dewa and Safitri 2021).

TikTok dirasakan memiliki kekuatan ataupun pengaruh dalam industri, sehingga menimbulkan kualitas akun yang menentukan strata maupun kredibilitas pemilik akun. Kredibilitas akun TikTok merupakan suatu hal yang cukup penting untuk berbagai kepentingan. Kredibilitas sebuah akun TikTok dapat diukur dari tingkat performa yang dihasilkan secara matematis. Dalam mengukur performa diperlukan skala pengukuran yang tertuang ke dalam rasio.

\section{METODELOGI PENELITIAN}

Penelitian ini menggunakan metode eksploratif kuantitatif untuk mengetahui kredibilitas dari performa akun TikTok 5 brand handphone di dunia Q1 2021. Metode eksploratif merupakan penelitian yang memiliki tujuan untuk melakukan eksplorasi atau memperdalam pengetahuan ataupun ide-ide baru mengenai suatu hal yang baru, guna merumuskan permasalahan secara terperinci (Maryam, Isrok'atun, and Aeni 2016).

Tujuan dari penelitian ini yaitu mengetahui nilai kredibillitas dari performa akun akun TikTok 5 brand handphone di dunia Q1 2021. Ada beberapa langkah yang harus dilakukan dalam penelitian ini, sehingga mampu menemukan peringkat pertama akun TikTok Vendor Smartphone di Indonesia yang memiliki performa terbaik. Langkah-langkah yang dilakukan pada penelitian ini, diantaranya yaitu : 


\section{Melakukan Eksplorasi Pada Website Untuk Menentukan Objek yang Akan Dianalisa.}

Eksplorasi ini dilakukan pada beberapa halaman website yang menyediakan informasi mengenai objek yang akan di teliti. Setelah ekslorasi selesai dilakukan, sehingga ditemukan nama-nama vendor smartphone di Indonesia yang akan dijadikan objek analisa. Setelah melakukan eksplorasi pada halaman website, maka langkah selanjutnya yaitu mencari nama akun TikTok dari masing-masing vendor smartphone. Pastikan semua vendor memiliki akun pada aplikasi sosial media TikTok.

2. Menghitung Nilai Rata-Rata Variable Dari Top 5 Vendor Smartphone di Indonesia. Pada langkah ini, peneliti menghitung nilai variable video comments dan variable video views. Variabel merupakan sesuatu yang memiliki nilai bervariasi dimana nilai tersebut dapat dijadikan sebagai dasar untuk empat data yang berbeda seperti rasio, skala, ordinal, nominal dan internal (Rankuti 2015). Untuk menghitung nilai rata-rata dari variabel video comments dan variabel video views yaitu dengan cara mengambil minimal 10 postingan kemudian di hitung sehingga menemukan nilai rata-rata dari masing-masing variabel.

\section{Menghitung Nilai Kredibilitas Rasio}

Untuk menghitung nilai kredibilitas dari video Like to video Share ratio, peneliti menggunakan cara membagi nilai variabel pertama dengan nilai variabel kedua. Jika video comments memiliki nilai 100 dan video views memiliki nilai 300, maka cara menghitungnya yaitu $100: 300=0,3$. Dengan begitu nilai dari video Like to video Share ratio adalah 0,3

\section{Menentukan Peringkat Pada Akun TikTok}

Pada langkah terakhir yang dilakukan pada penelitian ini yaitu menentukan peringkat pada masing-masing rasio yang ada. Pada penentuan peringkat perlu melihat karakteristik dari rasio yang di teliti. Jika karakteristik rasio merupakan rendah, maka objek yang memiliki nilai terendah akan mendapatkan angka 5 dan objek yang memiliki nilai tertinggi akan mendapatkan angka 1. Namun jika rasio memiliki karakteritik tinggi maka objek yang mendapatkan nilai tinggi akan mendapatkan angka 5 dan objek yang mendapatkan nilai terendah akan mendapatkan angka 1 . Setelah mendapatkan hasil kredibilitas ratio maka dapat disimpulkan objek yang mana mendapatkan peringkat 1 sampai dengan peringkat 5 .

\section{HASIL DAN PEMBAHASAN}

Ini merupakan akun tiktok dari 5 perusahaan handphone di Q1-2021, diantaranya :

\section{Samsung}




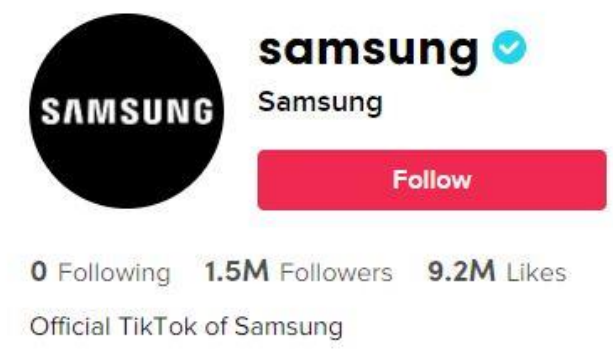

Gambar 1. Akun Tiktok Samsung

Sumber : https://www.tiktok.com/@samsung?

\section{Huawei}

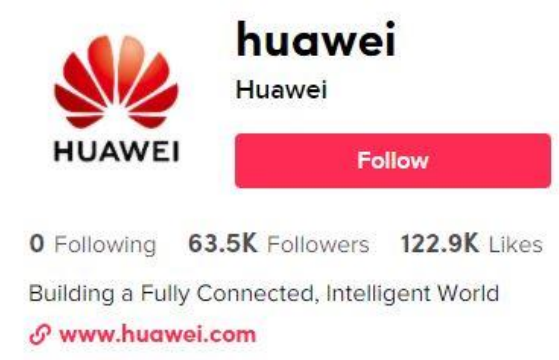

Gambar 2. Akun Tiktok Samsung

Sumber : https://www.tiktok.com/@ huawei?

\section{Oppo}

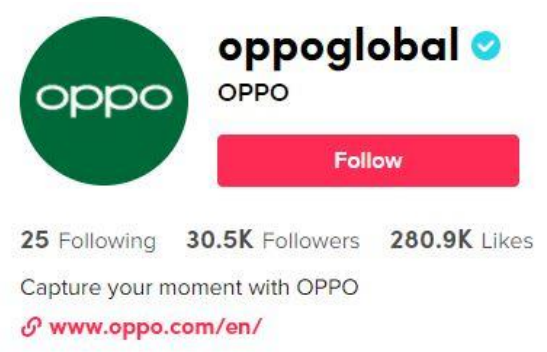

Gambar 3. Akun Tiktok Oppo

Sumber : https://www.tiktok.com/@oppoglobal? 


\section{Appel}

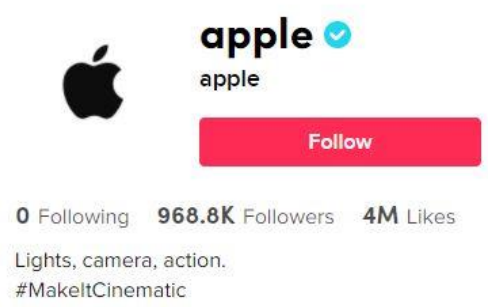

Gambar 4. Akun Tiktok Appel

Sumber : https://www.tiktok.com/@oppoglobal?

\section{Xiaomi}

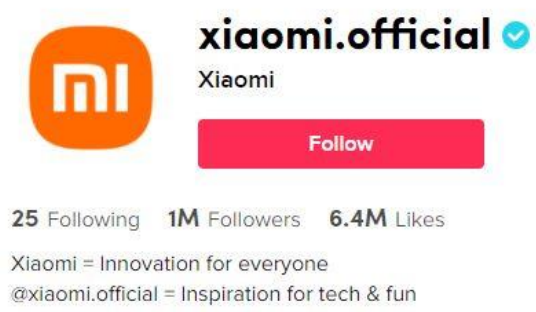

Gambar 5. Akun Tiktok Xiaomi

Sumber : https://www.tiktok.com/@xiaomi.official?lang=en

Dari kelima akun tiktok top 5 perusahaan handphone di dunia pada Q1 tahun 2021, Peneliti menemukan masing masing variabale untuk menghitung video like to video share pada masing masing video akun tersebut, pada akun tiktok terdapat 7 variable yang tesedia antara lain :

1. Likes

2. Folowers

3. Following

4. Video likes

5. Video comment

6. Video share

7. Video views

Dari ketujuh variable, peneliti hanya berfokus menganalisa variable 2 variable yaitu :

1. Video Likes

2. Video Share 
Dari kedua variable tersebut maka dilakukan teknik analisis dengan metode mencari nilai ratarata dari masing masing sepuluh postingan terakhir masing masing akun yang sudah di sampaikan. Untuk mencari nilai rata-rata dari variable video share dan video likes yaitu dengan mengambila minimal 10 vidio masing-masing postingan trakhir ,kemudian di hitung hinggga menemukan nilai rata rata dari masing masing-masing variable. Berikut Tabel hasil perhitungan nilai rata-rata akun pada top 5 brand handphone terlaris di dunia.

Table 1. Analisa Nilai Rata-Rata Nilai Variabel Video Comments dan Video Views Akun TikTok Samsung

\begin{tabular}{|c|c|c|c|}
\hline $\begin{array}{c}\text { Merek } \\
\text { handphone }\end{array}$ & No & $\begin{array}{c}\text { Video } \\
\text { likes }\end{array}$ & $\begin{array}{l}\text { Video } \\
\text { share }\end{array}$ \\
\hline \multirow[t]{6}{*}{ Samsung } & 1 & 1680 & 12 \\
\hline & 2 & 3610 & 83 \\
\hline & 3 & 6342 & 89 \\
\hline & 4 & 2120 & 31 \\
\hline & 5 & 1205 & 16 \\
\hline & 6 & 3151 & 61 \\
\hline & 7 & 1262 & 9 \\
\hline & 8 & 1222 & 26 \\
\hline & 9 & 3768 & 88 \\
\hline & 10 & 4685 & 88 \\
\hline Total & & 2904.5 & 50.3 \\
\hline
\end{tabular}

Sumber : pengolahan data excel

Table 2. Analisa Nilai Rata-Rata Nilai Variabel Video Comments dan Video Views Akun TikTok Huawai

\begin{tabular}{|l|l|c|c|}
\hline \begin{tabular}{c} 
Merek \\
\multicolumn{1}{c|}{$\begin{array}{c}\text { Mandphone } \\
\text { hand }\end{array}$}
\end{tabular} & $\begin{array}{c}\text { Vo } \\
\text { likes }\end{array}$ & $\begin{array}{c}\text { Video } \\
\text { share }\end{array}$ \\
\hline \multirow{4}{*}{ Huawai } & 1 & 6 & 1 \\
\cline { 2 - 4 } & 2 & 9 & 4 \\
\cline { 2 - 4 } & 3 & 19 & 14 \\
\cline { 2 - 4 } & 4 & 34000 & 291 \\
\cline { 2 - 4 } & 5 & 20000 & 193 \\
\cline { 2 - 4 } & 6 & 16 & 0 \\
\cline { 2 - 4 } & 7 & 120 & 21 \\
\cline { 2 - 4 } & 8 & 38 & 2 \\
\cline { 2 - 4 } & 9 & 35 & 1 \\
\cline { 2 - 4 } & 10 & 35 & 3 \\
\hline
\end{tabular}


Table 3. Analisa Nilai Rata-Rata Nilai Variabel Video Comments dan Video Views Akun TikTok Oppo

\begin{tabular}{|l|l|c|c|}
\hline $\begin{array}{c}\text { Merek } \\
\text { handphone }\end{array}$ & No & $\begin{array}{c}\text { Video } \\
\text { likes }\end{array}$ & $\begin{array}{c}\text { Video } \\
\text { Share }\end{array}$ \\
\hline \multirow{5}{*}{ Oppo } & 1 & 133 & 155 \\
\cline { 2 - 4 } & 2 & 21000 & 382 \\
\cline { 2 - 4 } & 3 & 624 & 148 \\
\cline { 2 - 4 } & 4 & 931 & 168 \\
\cline { 2 - 4 } & 5 & 184 & 129 \\
\cline { 2 - 4 } & 6 & 583 & 102 \\
\cline { 2 - 4 } & 7 & 328 & 103 \\
\cline { 2 - 4 } & 8 & 468 & 165 \\
\cline { 2 - 4 } & 9 & 24000 & 210 \\
\cline { 2 - 4 } & 10 & 22000 & 193 \\
\hline Total & & $\mathbf{7 0 2 5 . 1}$ & $\mathbf{1 7 5 . 5}$ \\
\hline
\end{tabular}

Sumber : pengolahan data excel

Table 4. Analisa Nilai Rata-Rata Nilai Variabel Video Comments dan Video Views Akun TikTok Appel

\begin{tabular}{|l|l|c|c|}
\hline $\begin{array}{c}\text { Merek } \\
\text { handphone }\end{array}$ & No & $\begin{array}{c}\text { Video } \\
\text { likes }\end{array}$ & $\begin{array}{c}\text { Video } \\
\text { share }\end{array}$ \\
\hline \multirow{5}{*}{ Appel } & 1 & 376000 & 3085 \\
\cline { 2 - 4 } & 2 & 293000 & 1292 \\
\cline { 2 - 4 } & 3 & 520000 & 4660 \\
\cline { 2 - 4 } & 4 & 417000 & 1208 \\
\cline { 2 - 4 } & 5 & 210000 & 2000 \\
\cline { 2 - 4 } & 6 & 522000 & 3000 \\
\cline { 2 - 4 } & 7 & 223400 & 3450 \\
\cline { 2 - 4 } & 8 & 1000 & 500 \\
\cline { 2 - 4 } & 9 & 500000 & 300000 \\
\cline { 2 - 4 } & 10 & 22000 & 5000 \\
\hline Total & & $\mathbf{3 0 8 4 4 0}$ & $\mathbf{3 2 4 1 9 . 5}$ \\
\hline
\end{tabular}

Sumber : pengolahan data excel 
Table 5. Analisa Nilai Rata-Rata Nilai Variabel Video Comments dan Video Views Akun TikTok Oppo Indonesia

\begin{tabular}{|c|l|c|c|}
\hline $\begin{array}{c}\text { Merek } \\
\text { handphone }\end{array}$ & No & $\begin{array}{c}\text { Video } \\
\text { likes }\end{array}$ & $\begin{array}{c}\text { Video } \\
\text { share }\end{array}$ \\
\hline Xiaomi & 1 & 52000 & 1050 \\
\cline { 2 - 4 } & 2 & 118000 & 2253 \\
\cline { 2 - 4 } & 3 & 79000 & 861 \\
\cline { 2 - 4 } & 4 & 1160 & 7 \\
\cline { 2 - 4 } & 5 & 394 & 0 \\
\cline { 2 - 4 } & 6 & 96 & 0 \\
\cline { 2 - 4 } & 7 & 401 & 1 \\
\cline { 2 - 4 } & 8 & 4687 & 69 \\
\cline { 2 - 4 } & 9 & 740 & 2 \\
\cline { 2 - 4 } & 10 & 862 & 422.9 \\
\hline Total & & 25734 & 6 \\
\hline
\end{tabular}

Sumber : pengolahan data excel

Kemudian ketika sudah menghitung nilai rata-rata, maka akan menemukan akhir nilai rata-rata pada setiap variable video likes dan video share, berikut adalah hasil pencarian rata-rata :

Table 6. Nilai Variable Pada Akun TikTok Top 5 Brand Handphone Terlaris Di Dunia

\begin{tabular}{|l|c|c|}
\hline \multicolumn{1}{|c|}{$\begin{array}{c}\text { Merek } \\
\text { handphone }\end{array}$} & $\begin{array}{c}\text { Video } \\
\text { Likes }\end{array}$ & $\begin{array}{c}\text { Video } \\
\text { share }\end{array}$ \\
\hline Samsung & 2904.5 & 50.3 \\
\hline Huawai & 5426.8 & 53 \\
\hline Oppo & 7025.1 & 175.5 \\
\hline Apple & 308440 & 32419.5 \\
\hline Xiaomi & 25734 & 422.9 \\
\hline
\end{tabular}

Sumber : pengolahan data excel

Akun tiktok memiliki 17 rasio yang relevan untuk mengukur kredibilitas pada masing masing akun, tetapi pada penelitian ini ,peneliti hanya berfokus untuk menghitung Video Likes to Video Share Ratio. Kemudian unutk menghitung Kredibilitas dari masing masing akun prusahaan dari brand handphone tersebut, peneliti metode perhitungan dengan cara variable 1 di bagi dengan variable 2, maka ditemukan hasil dari analisis rasio tersebut.

Table 7. Hasil Perhitungan Rasio 5 Brand Handphone Terlaris Di Dunia Pada Akun TikTok 


\begin{tabular}{|l|l|l|l|l|l|l|}
\hline No & Ratio & Samsung & Huawei & Oppo & Appel & Xiaomi \\
\hline \multirow{2}{*}{1} & Video Likes to & 0.0164335 & 0.00976634 & 0.0249818 & 0.1051079 & 0.0164335 \\
& Video Share & 1 & 5 & 5 & 6 & 1 \\
\hline
\end{tabular}

Pada Video Likes to Video Share ratio memiliki karakteristik yang tinggi, maka semakin angkanya/nilai nya tinggi yang dihasilkan maka semakin baik performa dari akun tersebut, Untuk memberikan peringkat peneliti memberikan angka $1-5$ untuk akun yang memiliki angka 5 merupakan nilai tertinggi sedangkan angka 1 melambangkan angka terendah sehingga di dapat hasil sebagai berikut :

\begin{tabular}{|l|l|l|l|l|l|l|}
\hline No & & Samsung & Huawei & Oppo & Appel & Xiaomi \\
\hline 1 & Peringkat & 2 & 4 & 1 & 5 & 3 \\
\hline
\end{tabular}

Dari table di atas maka ditemukan hasil dari peringkat Video Likes to Video share, pada urutan nilai krebilitas tertinggi dimiliki oleh apple dan peringkat kerebilitas terendah dimiliki oleh Oppo.

\section{Kesimpulan}

Tujuan dari penelitian ini adalah mengetahui kredibilitas performa dari akun TikTok Top 5 Brand Handphone di Indonesia menggunakan Video Likes to Video Share Ratio. Top 5 Brand Handphne tersebut diantaranya : Oppo, Samsung, Huawai, Xiaomi, dan Appel. Dari kelima vendor smartphone tersebut dapat disimpulkan bahwa :

1. Peringkat pertama diraih oleh brand Appel dengan nilai tertinggi yaitu 0.10510796

2. Peringkat kedua diraih oleh brand Samsung dengan nilai 0.01643351

3. Peringkat ketiga diraih oleh brand Xiaomi dengan nilai 0.01643351

4. Peringkat keempat diraih oleh brand Huawai dengan nilai 0.009766345

5. Peringkat kelima diraih oleh barnd Oppo dengan nilai terendah yaitu 0.10510796 


\section{DAFTAR PUSTAKA}

Dewa, Chriswardana Bayu, and Lina Ayu Safitri. 2021. "Pemanfaatan Media Sosial Tiktok Sebagai Media Promosi Industri Kuliner Di Yogyakarta Pada Masa Pandemi Covid-19 (Studi Kasus Akun TikTok Javafoodie)." Khasanah Ilmu - Jurnal Pariwisata Dan Budaya 12(1): 65-71.

Fauziah, Yuliani Resti. 2019. "Konsep Diri Remaja Pengguna Aplikasi Tik Tok Di Kota Bandung.” Jurnal Ilmu Komunikasi (112): 1-2.

Permana, I Putu Hendika, and Ni Putu Suci Meinarni. 2021. "Ratio Analysis on Tiktok (Social Media) for Qualitative Research Using Explorative Methods." Jurnal Ekonomi \& Bisnis JAGADITHA 8(1): 30-38. 